\title{
Action Potentials Are Required for the Lateral Transmission of Glycinergic Transient Inhibition in the Amphibian Retina
}

\author{
Paul B. Cook, ${ }^{1}$ Peter D. Lukasiewicz, ${ }^{2}$ and John S. McReynolds ${ }^{1}$ \\ ${ }^{1}$ Department of Physiology, University of Michigan, Ann Arbor, Michigan 48109, and ${ }^{2}$ Department of Ophthalmology and \\ Visual Science, Washington University, St. Louis, Missouri 63110
}

Transient lateral inhibition (TLI), the suppression of responses of a ganglion cell to light stimuli in the receptive field center by changes in illumination in the receptive field surround, was studied in light-adapted mud puppy and tiger salamander retinas using both eyecup and retinal slice preparations. In the eyecup, TLI was measured in on-off ganglion cells as the ability of rotating, concentric windmill patterns of 500-1200 $\mu \mathrm{m}$ inner diameter to suppress the response to a small spot stimulus in the receptive field center. Both the suppression of the spot response and the hyperpolarization produced in ganglion cells by rotation of the windmill were blocked in the presence of $2 \mu \mathrm{M}$ strychnine or $500 \mathrm{~nm}$ tetrodotoxin (TTX), but not by $150 \mu \mathrm{M}$ picrotoxin. In the slice preparation in which GABA-mediated currents were blocked with picrotoxin, IPSCs elicited by diffuse illumination were blocked by strychnine and strongly reduced by TTX. The TTX-resistant component was probably attributable to illumination of the receptive field center. TTX had a much greater effect in reducing the glycinergic inhibition elicited by laterally displaced stimulation versus nearby focal electrical stimulation. Strychnine enhanced light-evoked excitatory currents in ganglion cells, but this was not mimicked by TTX. The results suggest that local glycinergic transient inhibition does not require action potentials and is mediated by synapses onto both ganglion cell dendrites and bipolar cell terminals. In contrast, the lateral spread of this inhibition (at least over distances $>250 \mu \mathrm{m}$ ) requires action potentials and is mainly onto ganglion cell dendrites.

Key words: retina; ganglion cell; receptive field; lateral inhibition; glycine; action potentials
Changes in illumination (the onset, offset, or movement of a light stimulus) cause inhibition of ganglion cells over a wide area of the retina. This mechanism, known as change-sensitive or transient lateral inhibition (TLI), is thought to be mediated in the inner plexiform layer by wide-field transient (on-off) amacrine cells (Werblin, 1972; Werblin and Copenhagen, 1974; Thibos and Werblin, 1978). The idea that TLI might be mediated by glycine was first suggested by the finding that in mud puppy ganglion cells glycinergic inhibitory inputs were activated at the onset and termination of light stimuli but not during steady illumination (Belgum et al., 1984). A likely source of such input would be on-off amacrine cells, and in the closely related tiger salamander retina most wide-field on-off amacrine cells are immunoreactive for glycine (Yang et al., 1991). The wide-field transient amacrine cells in tiger salamander retina receive excitatory inputs near their somas and generate action potentials that propagate away from the soma over long processes (Cook and Werblin, 1994), suggesting that the lateral spread of TLI may be via action potentials. It is known that action potentials increase the spread of signals within some wide-field amacrine cells (Barnes and Werblin, 1987; Cook and Werblin, 1994; Bloomfield, 1996), but it is not yet known how action potential-dependent signaling in amacrine cells affects ganglion cell responses to light. In the present study, we measured the effects of tetrodotoxin (TTX) and the glycine antagonist strychnine on light-evoked TLI in ganglion

\footnotetext{
Received Nov. 20, 1997; revised Jan. 5, 1998; accepted Jan. 7, 1998

This work was supported by National Institutes of Health Research Grants EY01653 and EY08922, Core Grants EY07003 and EY02687, and a grant from Research to Prevent Blindness to P.D.L.

Correspondence should be addressed to Dr. Paul B. Cook, Department of Physiology, The University of Michigan Medical School, Ann Arbor, MI 48109-0622. Copyright (C) 1998 Society for Neuroscience $0270-6474 / 98 / 182301-08 \$ 05.00 / 0$
}

cells in mud puppy and tiger salamander eyecup preparations and on light-evoked EPSCs and IPSCs in ganglion cells in the salamander retinal slice preparation. The results indicate that TLI in ganglion cells involves glycinergic inhibition onto ganglion cells, that transient glycinergic inhibition is elicited by both center and surround illumination, and that action potentials are required for the lateral spread of this inhibitory signal in the retina over distances $>250 \mu \mathrm{m}$. There is also a presynaptic component of transient glycinergic inhibition onto bipolar cells, but this appears to be mainly from nearby amacrine cells. This is the first demonstration that action potentials are required for the lateral transmission of signals affecting the receptive field organization of retinal ganglion cells.

\section{MATERIALS AND METHODS}

Eyecup preparations were made from mud puppies (Necturus maculosus) and larval tiger salamanders (Ambystoma tigrinum). Mud puppies were obtained from Kons Scientific (Germantown, WI), and tiger salamanders were from Charles Sullivan (Nashville, TN). The care and use of animals was in accordance with the University of Michigan and the Society for Neuroscience policies on the use of animals in research. Details of the preparation, electrical recording, and light stimulation are described elsewhere (Cook and McReynolds, 1998). Intracellular voltage recordings were made from on-off ganglion cells using micropipettes, filled with $2 \mathrm{M}$ potassium acetate (resistance $300-500 \mathrm{M} \Omega$ ), and conventional electronics. Light stimuli were a $400 \mu \mathrm{m}$ diameter spot in the receptive field center (determined before the experiment) and concentric annuli [inner diameter (i.d.) 1200 or $500 \mu \mathrm{m}$, outer diameter (o.d.) $2600 \mu \mathrm{m}$ ]. All light stimuli were $560 \mathrm{~nm}$, the intensity of which was controlled with calibrated neutral density filters and expressed as $\log$ quanta $/ \mathrm{cm}^{2} / \mathrm{sec}$. Retinas were superfused with amphibian Ringer's solution (in $\mathrm{mm} / \mathrm{l}$ ): $\mathrm{NaCl} 110, \mathrm{KCl} 2.5, \mathrm{CaCl}_{2} 1.8, \mathrm{MgCl}_{2} 1.2$, glucose 11, HEPES buffer 5, adjusted to $\mathrm{pH} 7.8$ with $\mathrm{NaOH}$. Drugs were added by switching to another Ringer's solution containing either $2 \mu \mathrm{M}$ strychnine, $150 \mu \mathrm{M}$ picrotoxin, or $500 \mathrm{~nm}$ TTX. 

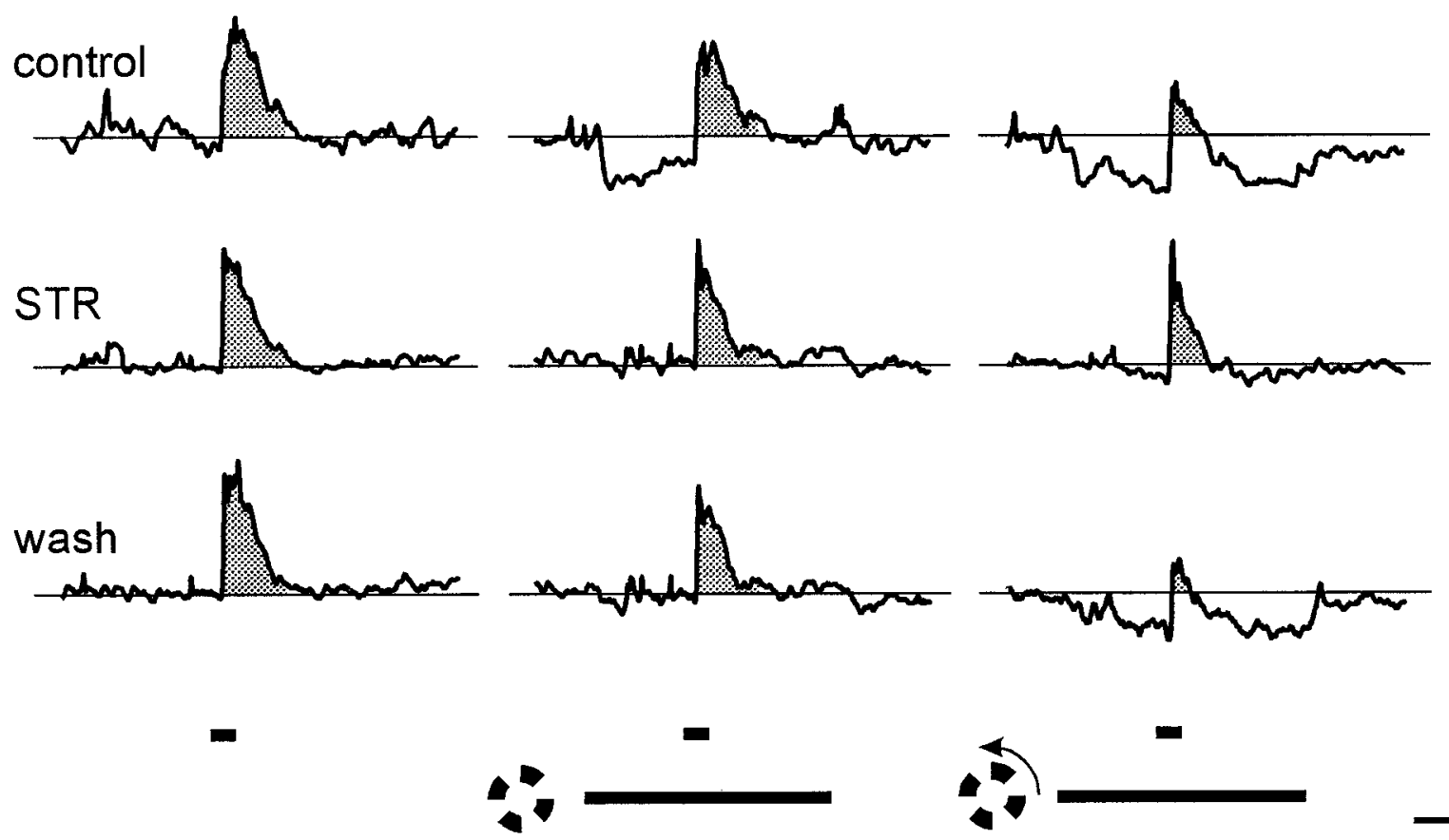

$10 \mathrm{mv}$

$1 \mathrm{sec}$

Figure 1. Strychnine blocks TLI in ganglion cells. Responses are from an on-off ganglion cell in tiger salamander eyecup. Each trace is the average of four to eight responses that had been filtered to eliminate action potentials (see Methods and Materials). Each of the three groups of traces shows the average response to a 400- $\mu$ m-diameter spot alone (left $)$ and in the presence of a windmill pattern (1200 $\mu \mathrm{m}$ i.d., $2600 \mu \mathrm{m}$ o.d.) that was either stationary (middle) or rotating (right). The timing of the spot and windmill stimuli are indicated by the horizontal bars at the bottom. Spot and windmill intensity were both $8.4 \log$ quanta. Responses in the middle row of traces were obtained after 5 min in $2 \mu \mathrm{M}$ strychnine, and those in the bottom row of traces were obtained 20 min after return to control Ringer's solution. Resting potential in darkness was $-50 \mathrm{mV}$ in control Ringer's solution and -53 $\mathrm{mV}$ in the presence of strychnine.

One measure of TLI in the retina is the degree to which a response of the ganglion cell to illumination of the receptive field center is suppressed by rotation of a concentric windmill pattern (Werblin, 1972; Werblin and Copenhagen, 1974; Thibos and Werblin, 1978). In the present experiments, this measurement of TLI was made by comparing the response to a $400-\mu \mathrm{m}$-diameter spot in the presence of a concentric windmill pattern (i.d. 500 or $1200 \mu \mathrm{m}$, o.d. $2600 \mu \mathrm{m}$ ) that was either stationary or rotating at $0.25 \mathrm{rps}$. Because TLI is the additional suppression produced by rotation of the windmill pattern, the percentage suppression attributed to TLI is $100 \cdot\left(R_{\text {stat }}-R_{\text {rot }}\right) / R_{\text {stat }}$, where $R_{\text {stat }}=$ spot response in the presence of the stationary windmill, and $R_{\mathrm{rot}}=$ spot response in the presence of the rotating windmill. Voltage responses were digitized at $1 \mathrm{KHz}$. Four to eight responses in each condition were averaged after digital filtering using a Gaussian with $-3 \mathrm{~dB}$ rolloff at $10 \mathrm{~Hz}$, and the area of the EPSP above the baseline (dark) potential was calculated between 250 and $1250 \mathrm{msec}$ after the onset of the spot stimulus. The spot response measured in this way correlated well with the number of action potentials produced by the spot stimulus.

Retinal slice preparations (200 and $400 \mu \mathrm{m}$ thick) were made from larval tiger salamander eyes as described in detail by Lukasiewicz et al. (1994). Whole-cell voltage-clamp recordings were made using patch electrodes containing (in $\mathrm{mm} / \mathrm{l}$ ): cesium gluconate 99 , tetraethylammonium chloride 8, $\mathrm{NaCl} 3.4, \mathrm{MgCl}_{2}$ 0.4, $\mathrm{CaCl}_{2}$ 0.4, EGTA 11, HEPES buffer 10, adjusted to $\mathrm{pH} 7.7$ with $\mathrm{NaOH}$. The bath solution contained (in $\mathrm{mm} / \mathrm{l}$ ): $\mathrm{NaCl} 112, \mathrm{KCl} 2, \mathrm{CaCl}_{2} 2, \mathrm{MgCl}_{2} 1$, glucose 5, HEPES buffer 5, adjusted to $\mathrm{pH} 7.8$ with $\mathrm{NaOH}$. Light stimuli were diff use flashes of white light in which the intensity at the retinal surface was equivalent to $3.6 \times$ $10^{8}$ quanta $\cdot \mathrm{cm}^{2-1} \cdot \mathrm{sec}^{-1}$ at $560 \mathrm{~nm}$. The slice was superfused and drugs were applied through a large diameter pipette connected to a gravity-driven superfusion system that permitted rapid switching between control and test solutions. Ganglion cells were identified by the location of their somas in the ganglion cell layer and large $(>1000 \mathrm{pA})$ inward currents elicited by depolarizing voltage steps. Some cells were also identified visually by inclusion of Lucifer yellow in the recording pipette.
Current recordings from slice preparations were digitized at $2 \mathrm{kHz}$. $\mathrm{GABA}_{\mathrm{A}^{-}}$and $\mathrm{GABA}_{\mathrm{C}^{-}}$-mediated synaptic currents were blocked by the presence of $150 \mu \mathrm{M}$ picrotoxin in the superfusate. In some experiments the retina was electrically stimulated by application of $1 \mathrm{msec}$ positive current pulses $(0.5-2 \mu \mathrm{A})$ using a constant current stimulator (Grass S48 with stimulus isolation unit PSIU6) through a Ringer's solution-filled pipette, the tip of which was located in the outer plexiform layer (OPL) $\sim 300 \mu \mathrm{m}$ lateral to the recording site. The return path for the current was a silver-silver chloride electrode, separate from the recording ground electrode, connected to the bath through an agar bridge filled with $1 \mathrm{M}$ $\mathrm{KCl}$. The OPL site was used because it produced larger and more consistent responses than when the electrode was located in the inner retina. Focal application (puffs) of glycine was made by pressure $(5 \mathrm{msec}$ at $5 \mathrm{psi}$ ) ejection (Picospritzer) from a pipette containing $0.5 \mathrm{~mm}$ glycine. Strychnine and picrotoxin were obtained from Sigma (St. Louis, MO), and TTX was from Research Biochemicals (Natick, MA).

\section{RESULTS}

\section{Eyecup experiments}

As previously shown in mud puppy, both sustained and transient lateral inhibition in tiger salamander ganglion cells are strongly affected by the state of adaptation. Light adaptation enables TLI (it is disabled in dark-adapted retinas) and reduces the amount of lateral inhibition produced by distant stationary stimuli (Cook and McReynolds, 1998). Therefore, to study the effects of pharmacological agents on TLI, most of the eyecup experiments reported here were performed under conditions in which TLI was relatively strong and suppression by stationary windmills was relatively weak, i.e., using light-adapted retinas and windmill stimuli of large $(1200 \mu \mathrm{m})$ inner diameter. 

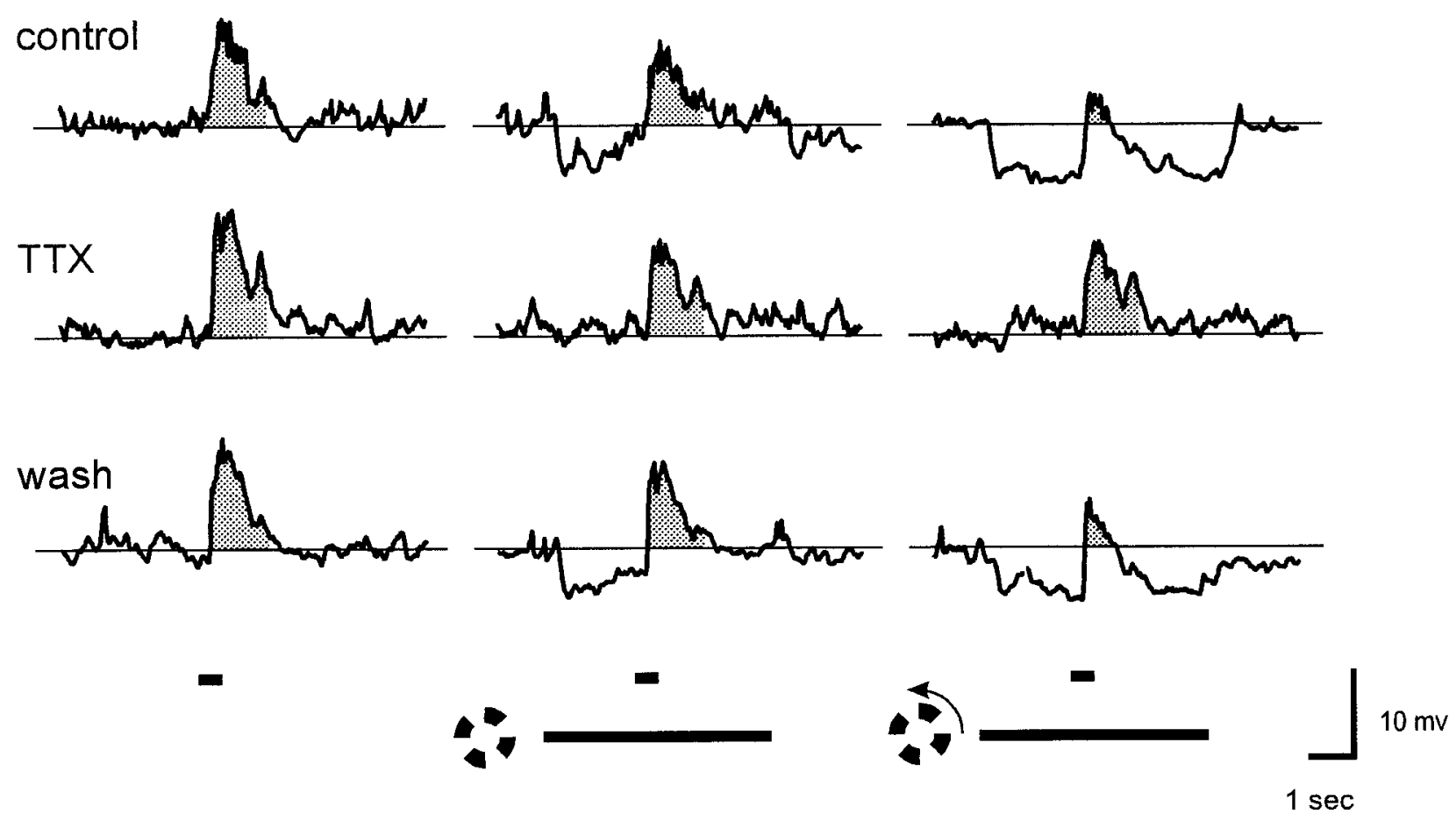

Figure 2. TTX blocks TLI in ganglion cells. Responses are from the same cell as in Figure 1. Except for the use of TTX rather than strychnine, all conditions are the same as in Figure 1. The responses in the middle row of traces were obtained after 2 min in $500 \mathrm{~nm}$ TTX, and those in the bottom row of traces were obtained $10 \mathrm{~min}$ after return to control Ringer's solution. Resting potential was $-51 \mathrm{mV}$ in both control Ringer's solution and TTX.

\section{Strychnine blocks transient lateral inhibition in ganglion cells}

Figure 1 shows responses of an on-off ganglion cell from tiger salamander retina to a $400 \mu \mathrm{m}$ diameter spot centered in the receptive field under various conditions. Each row of traces shows averaged responses to the spot alone (left), and to the same spot in the presence of a $1200 \mu \mathrm{m}$ i.d. windmill stimulus that was either stationary (middle) or rotating (right), as indicated by the stimulus markers at the bottom of the figure. In these traces the shaded areas indicate the area of EPSP above the baseline (resting potential in darkness) that was measured for quantifying the effects of the windmill patterns (see Methods and Materials). In control Ringer's solution (top row), there was a transient hyperpolarization at the onset of the stationary windmill that became sustained when the windmill was rotating. The spot response was affected only slightly by the stationary windmill but was shifted to a more negative potential level when the windmill was rotating. Although not shown here because the action potentials were filtered out, both the number of spikes generated by the spot stimulus and the maximum spike frequency were significantly reduced while the windmill was rotating. The changes in spike number and maximum spike frequency correlated well with the changes in EPSP area above baseline (see Methods and Materials). The middle row of traces in Figure 1 shows responses to the same stimuli 5 min after the addition of $2 \mu \mathrm{M}$ strychnine to the superfusate. Strychnine blocked the transient hyperpolarization at the onset of the stationary windmill, the sustained hyperpolarization produced by the rotating windmill, and the suppression of the spot response by rotation of the windmill. Strychnine also altered the kinetics of the spot response (see below). The bottom row of traces shows the responses to these same stimuli $20 \mathrm{~min}$ after return to control Ringer's solution. Recovery from strychnine was slow, but complete recovery was usually observed if the recording could be maintained for $>30 \mathrm{~min}$. Similar results of 2 $\mu \mathrm{M}$ strychnine were seen in all on-off ganglion cells tested with $1200 \mu \mathrm{m}$ i.d. windmill stimuli $(n=6)$, as summarized (see Fig. 3). Strychnine caused a significant reduction in TLI (paired Student's $t$ test; $p=0.004)$. The small amount of suppression produced by stationary $1200 \mu \mathrm{m}$ i.d. windmills in these light-adapted retinas was not significantly reduced by strychnine $(p=0.30)$.

Although not shown here, strychnine also blocked TLI elicited by windmills of smaller inner diameter $(500 \mu \mathrm{m})$. With the smaller inner diameter windmill patterns, there was also significant suppression of the spot response when the windmill was stationary, but this sustained lateral inhibition (Cook and McReynolds, 1998) was not reduced by strychnine.

The same experiments were repeated using the $\mathrm{GABA}_{\mathrm{A}}$ / $\mathrm{GABA}_{\mathrm{C}}$ antagonist picrotoxin $(150 \mu \mathrm{M})$. In contrast to strychnine, picrotoxin did not reduce TLI (see Fig. 3). Picrotoxin also did not reduce the transient hyperpolarization at the onset of a stationary windmill stimulus or the sustained hyperpolarization produced by rotating the windmill, indicating that neither $\mathrm{GABA}_{\mathrm{A}}$ nor $\mathrm{GABA}_{\mathrm{C}}$ receptors are necessary for the activation of the glycinergic inhibition associated with TLI.

\section{Tetrodotoxin blocks the lateral spread of transient lateral inhibition in the retina}

To test whether the lateral spread of TLI in the retina requires action potentials, we measured the effects of steady versus rotating $1200 \mu \mathrm{m}$ i.d. windmills before and after blocking action potential generation with $500 \mathrm{~nm}$ TTX. Figure 2 shows that in the presence of TTX neither the stationary nor rotating windmill stimuli produced any detectable hyperpolarization. The stationary windmill caused a slight suppression of the spot response, but there was no further suppression of the spot response when the windmill was rotating. Thus, TTX had the same effects as strych- 


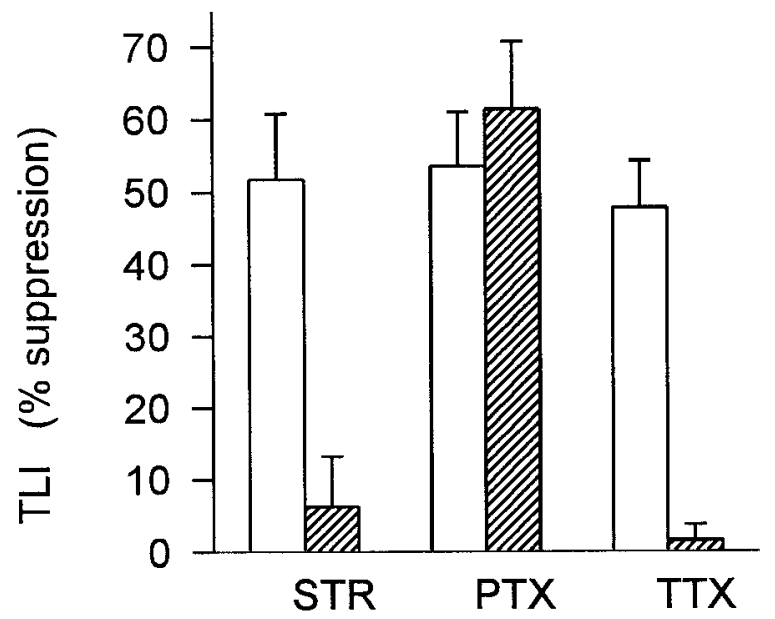

Figure 3. Summary of effects of strychnine, picrotoxin, and tetrodotoxin on transient lateral inhibition in ganglion cells. TLI was elicited by 1200 $\mu \mathrm{m}$ i.d. windmill stimuli, intensity $8.4 \log$ quanta. Ordinate indicates the magnitude of TLI expressed as percentage suppression of the spot response by rotation of the windmill pattern, calculated as described in Materials and Methods. Each pair of bars shows TLI in control Ringer's solution (open) and in the presence of the indicated drug (hatched): $2 \mu \mathrm{M}$ strychnine (STR) ( $n=6$ cells), $150 \mu \mathrm{M}$ picrotoxin $(P T X)(n=3$ cells), and $500 \mathrm{~nm}$ tetrodotoxin $(T T X)(n=6$ cells $)$. In three of the cells both strychnine and TTX were tested. Error bars indicate 1 SEM. Strychnine and TTX each caused a significant decrease in TLI ( $p=0.004$ and 0.003 , respectively; paired Student's $t$ test), but picrotoxin did not $(p=0.45)$. For comparison, the data shown above include only those cells in which the spot and windmill intensities were $8.4 \log$ quanta, but similar results were obtained in other cells from both tiger salamander and mud puppy using windmill stimuli of other intensities.

nine on all of the manifestations of TLI elicited by the $1200 \mu \mathrm{m}$ i.d. windmill stimulus: it blocked the transient hyperpolarization at the onset of the stationary windmill, the sustained hyperpolarization produced when the windmill was rotating, and the suppression of the spot response by the rotating windmill.

Figure 3 summarizes the effect of $500 \mathrm{~nm}$ TTX on the six cells tested with $1200 \mu \mathrm{m}$ i.d. windmill patterns. TTX caused a significant reduction in TLI $(p=0.003)$. TTX also blocked TLI elicited by $500 \mu \mathrm{m}$ i.d. windmill stimuli (not shown), indicating that the lateral spread of TLI over distances as short as $250 \mu \mathrm{m}$ requires action potentials.

\section{Strychnine, but not tetrodotoxin, blocks transient inhibition produced by illumination of the receptive field center}

In addition to blocking TLI elicited by rotating windmill patterns, strychnine also blocked inhibition elicited by illumination of the receptive field center. Figure 4 shows responses to a centered $400-\mu \mathrm{m}$-diameter spot in the absence of a windmill pattern. The thick trace shows the response in control Ringer's solution. In the presence of $2 \mu \mathrm{M}$ strychnine, the response to the spot reached its peak earlier and began to decay sooner than in the absence of strychnine. The increase in rate of rise of the spot response probably results from blocking glycinergic transient inhibition elicited by the onset of the spot stimulus (Belgum et al., 1984). The effect of strychnine on the decay of the spot response is more difficult to explain, but it may be attributable to removing glycinergic inhibition of a GABAergic input (Roska and Werblin, 1997; Zhang et al., 1997), either to the ganglion cell or onto the bipolar terminals responsible for the EPSP. TTX (500 nM) did not mimic this effect of strychnine, suggesting that glycine release from the

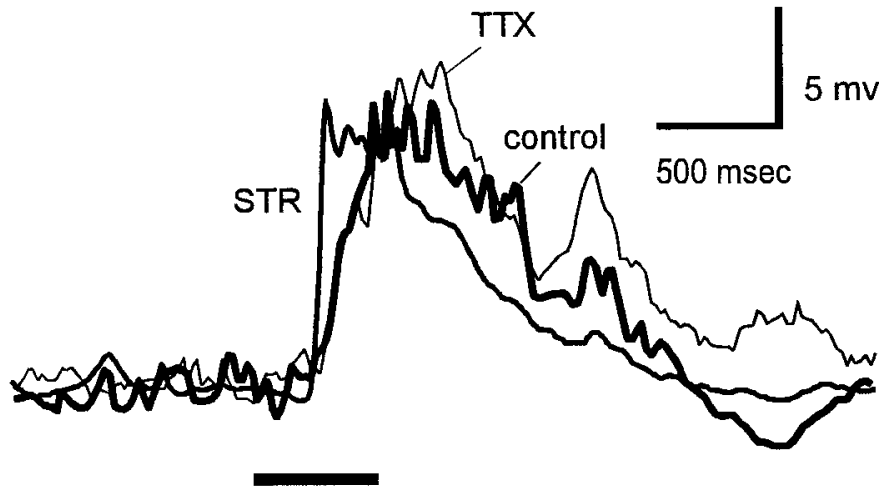

Figure 4. Effect of strychnine and TTX on the waveform of the response elicited by center illumination. The traces show superimposed responses of a tiger salamander on-off ganglion cell to a 400 - $\mu$ m-diameter spot (8.4 $\log$ quanta) in the receptive field center in control Ringer's solution, in the presence of $2 \mu \mathrm{M}$ strychnine (STR), and in the presence of $500 \mathrm{~nm}$ TTX. Each trace is the average of eight responses. The retina was washed with control Ringer's solution for 20 min between the two drug applications. Resting potential was $-55 \mathrm{mV}$ in all traces.

nearby amacrine cells (those stimulated by the small spot) does not require action potentials.

\section{Strychnine and tetrodotoxin block the conductance increase associated with transient lateral inhibition}

The above results indicate that TLI is mediated by glycine but does not distinguish between a direct action (inhibition of ganglion cells) and an indirect action (inhibition of bipolar cell terminals). To test whether TLI involves direct inhibition of ganglion cells we measured the changes in ganglion cell input conductance produced by stationary and rotating windmill patterns. In the cells used in these experiments, the effects of the $1200 \mu \mathrm{m}$ i.d. windmill patterns on the spot response were similar to those described above. The stationary windmill caused only a transient hyperpolarization and did not significantly suppress the spot response, whereas rotation of the windmill caused a sustained hyperpolarization and significant suppression of the spot response. Figure 5 shows the voltage deflections produced in a ganglion cell by a $-0.1 \mathrm{nA}$ current pulse ( $250 \mathrm{msec}$ duration) in the dark (left), and in the presence of a $1200 \mu \mathrm{m}$ i.d. windmill that was either stationary (middle) or rotating (right). Each trace is the average of 20 responses to the current pulse. The hyperpolarizing voltage deflection produced by the current pulse in darkness was balanced using the bridge circuit of the amplifier, so that an upward voltage deflection indicates an increase in conductance relative to the dark level. The stationary windmill did not cause a sustained hyperpolarization or a change in membrane conductance, whereas rotation of the windmill caused an increase in membrane conductance and a sustained hyperpolarization (note downward shift of right trace). The increase in conductance indicates that TLI involves a direct inhibition of ganglion cells. In the three ganglion cells tested, both strychnine and TTX blocked the hyperpolarization and conductance increase associated with TLI. Experiments in the slice preparation (see below) indicated that there is also a presynaptic component of transient glycinergic inhibition.

\section{Experiments in the retinal slice preparation}

Experiments in tiger salamander retinal slice preparation were undertaken to determine whether glycinergic inhibitory currents in ganglion cells also consisted of a lateral component that re- 


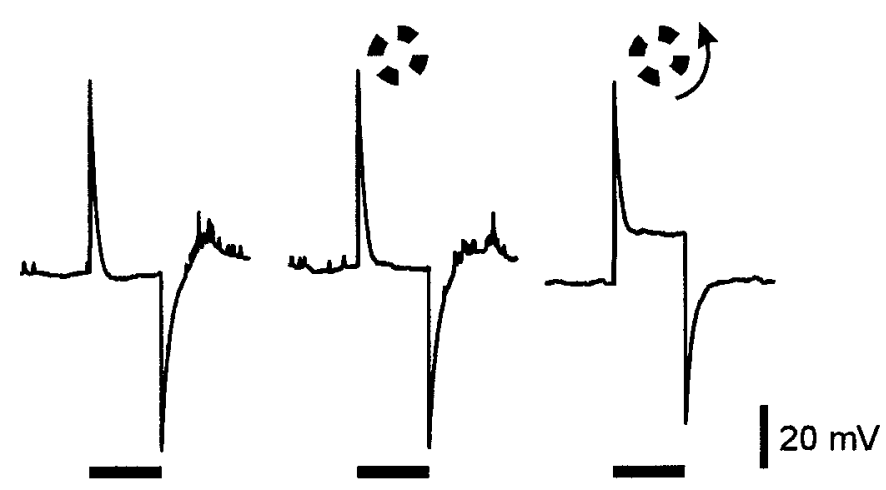

Figure 5. TLI is associated with an increase in ganglion cell conductance. Each trace shows voltage deflections produced in a tiger salamander ganglion cell by a $-0.1 \mathrm{nA}$ current pulse ( $250 \mathrm{msec}$ duration) in the dark (left) and in the presence of a $1200 \mu \mathrm{m}$ i.d. windmill that was stationary (middle) or rotating (right). Each trace is the average of 20 responses to the current pulse. The voltage deflection produced by the current pulse in darkness was balanced using the bridge circuit of the amplifier, so that a positive voltage deflection indicates an increase in conductance. The downward shift of the right trace indicates the amount of sustained hyperpolarization $(-7 \mathrm{mV})$ produced by the rotating windmill. Resting potential was $-58 \mathrm{mV}$.

quired action potentials and a local component that did not. We also wanted to determine whether there was a presynaptic component of TLI mediated by glycinergic inhibition of bipolar cells, and if so, whether this presynaptic inhibition also had TTXsensitive and TTX-resistant components. The presynaptic component was studied by recording the excitatory inputs to ganglion cells when inhibitory inputs to the recorded cell were eliminated by voltage-clamping the ganglion cells at the reversal potential for chloride ions. The results reported here were obtained only from ganglion cells that were reasonably well space-clamped, as evidenced by reversal of the excitatory and inhibitory currents near their expected reversal potentials ( 0 and $-60 \mathrm{mV}$, respectively) and absence of the spontaneous, voltage-gated inward currents usually seen in poorly space-clamped spiking cells.

\section{Tetrodotoxin blocks the lateral spread of transient glycinergic inhibition}

The whole-cell recordings in Figure 6 show light-evoked, glycinemediated IPSCs in an on-off ganglion cell. $\mathrm{GABA}_{\mathrm{A}^{-}}$and $\mathrm{GABA}_{C}$-mediated responses were eliminated by $150 \mu \mathrm{M}$ picrotoxin in the bathing solution, and excitatory currents were eliminated by voltage-clamping the cells at $0 \mathrm{mV}$, which is near the reversal potential for the excitatory input. Under these conditions, diffuse illumination elicited an outward current that was completely blocked by $2 \mu \mathrm{M}$ strychnine (Fig. $6 A$ ), indicating that this current was entirely glycinergic. The light-evoked glycinergic current was a transient response elicited by the onset of illumination, because even with long (3-5 sec duration) light stimuli the IPSC was transient and decayed to zero in $<1 \mathrm{sec}$. In the same cell, 500 nM TTX strongly reduced this light-evoked current (Fig. $6 B$ ). Because the diffuse light stimulus also illuminated the receptive field center, the small TTX-resistant component of the inhibitory current was probably attributable to glycine released by amacrine cells near the receptive field center. This is consistent with the finding in eyecup preparations that illumination of the ganglion cell receptive field center activated glycinergic transient inhibition that was not blocked by TTX (Fig. 4).

Although separate stimulation of the receptive field center and surround with light stimuli was not possible in the slice prepara-
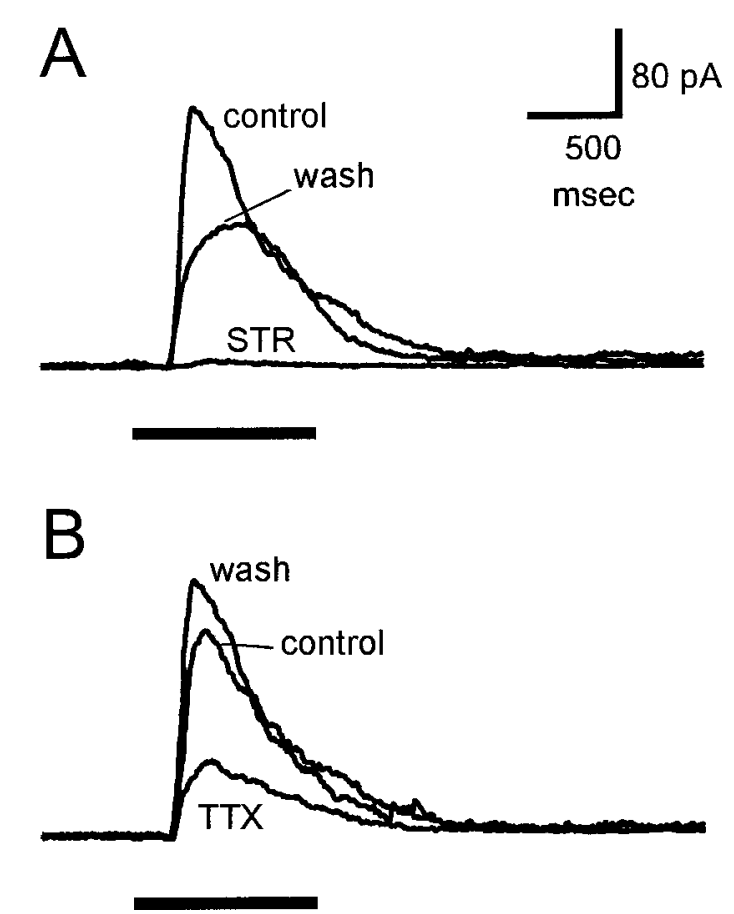

Figure 6. Effects of strychnine and TTX on light-evoked inhibitory currents in ganglion cells. Responses are from an on-off ganglion cell in a tiger salamander slice preparation. The control Ringer's solution contained $150 \mu \mathrm{M}$ picrotoxin to block GABA-mediated responses. The cell was voltage-clamped at $0 \mathrm{mV}$ to eliminate glutamate-mediated excitatory currents. Horizontal bars below responses indicate duration of diff use light stimulus. $A$, Currents recorded in control solution (control), in the presence of $2 \mu \mathrm{M}$ strychnine $(S T R)$, and $20 \mathrm{~min}$ after return to control solution (wash). B, Currents recorded in control solution (control), in the presence of $500 \mathrm{nM}$ TTX, and $10 \mathrm{~min}$ after return to control solution (wash). All responses were from the same cell. Holding current was $20 \mathrm{pA}$ in $A$ and $34 \mathrm{pA}$ in $B$. Calibration bars are for both $A$ and $B$.

tion, we tested the hypothesis that TTX blocked only the glycinergic inhibition from laterally distant sources by comparing the effects of TTX on inhibition produced by local and laterally displaced electrical stimulation of the retina. Figure 7 shows the effects of TTX on glycinergic IPSCs elicited by focal electrical stimulation of the retina directly above the recording site $(A)$, and $\sim 300 \mu \mathrm{m}$ lateral to the recording site $(B)$. The cells were voltageclamped at $0 \mathrm{mV}$ to eliminate excitatory currents, and the bath contained $150 \mu \mathrm{M}$ picrotoxin to eliminate GABA-mediated responses. Under these conditions the IPSCs elicited by electrical stimulation were purely glycinergic because they were completely blocked in the presence of $2 \mu \mathrm{M}$ strychnine. TTX reduced the glycinergic IPSC elicited by laterally displaced electrical stimuli (Fig. $7 B$ ) to a much greater extent than it reduced that elicited by electrical stimuli near the recording site (Fig. 7A). Although the local and laterally displaced electrical stimulations were made in different cells, the differential effect of TTX on inhibition from local versus laterally displaced electrical stimulation was quite clear. For electrical stimulation directly over the recording site, TTX reduced the IPSC area by $18.8 \pm 11.3 \%$ ( $n=4$ cells), and for laterally displaced electrical stimulation TTX reduced the IPSC area by $64.3 \pm 12.0 \%$ ( $n=6$ cells $)$.

Another observation supporting the idea that TTX blocked primarily the lateral spread of glycinergic inhibition is that TTX caused much less reduction in the IPSCs evoked by diffuse illumination in thin $(200 \mu \mathrm{m})$ slices than in thick $(400 \mu \mathrm{m})$ slices, 

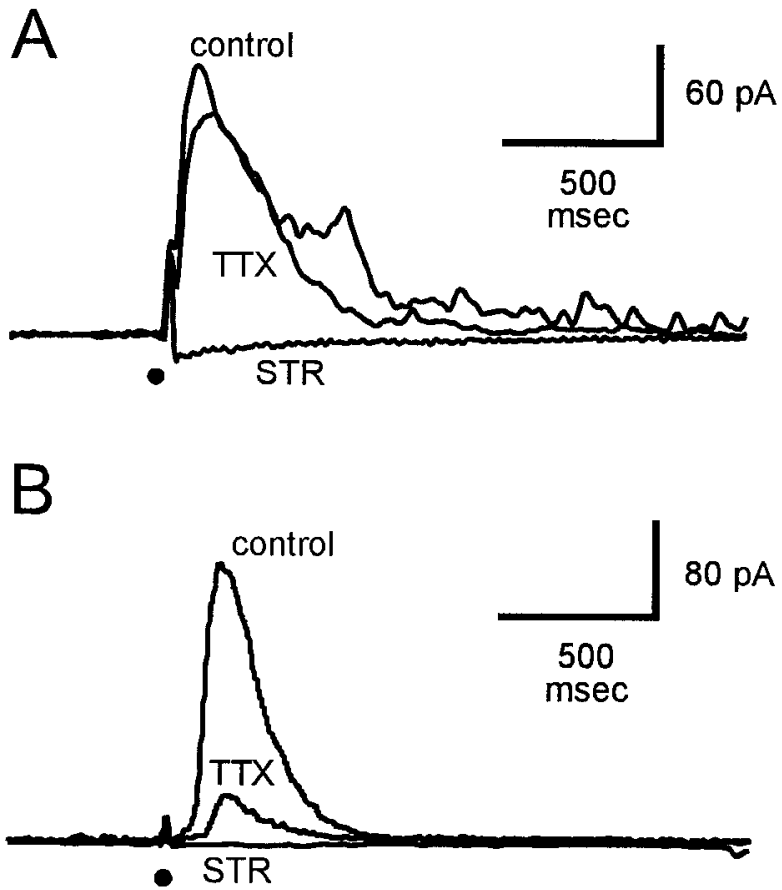

Figure 7. Effect of strychnine and TTX on glycinergic inhibitory currents elicited by electrical stimulation. IPSCs were recorded from ganglion cells held at $0 \mathrm{mV}$ to eliminate excitatory currents, and the control Ringer's solution contained $150 \mu \mathrm{M}$ picrotoxin to block GABA-mediated responses. Responses were elicited by $1 \mathrm{msec}, 1 \mu \mathrm{A}$ current pulses applied through a pipette located in the OPL directly over the recording site $(A)$ and $\sim 300 \mu \mathrm{m}$ lateral to the recording site $(B)$. Superimposed traces show current recorded under control conditions (control), in the presence of 2 $\mu \mathrm{M}$ strychnine (STR), and in the presence of $500 \mathrm{nM}$ TTX. $A$ and $B$ were from different cells. Holding current was $15 \mathrm{pA}$ in $A$ and $12 \mathrm{pA}$ in $B$. The dot below traces indicates time of electrical stimulation.

presumably because in the thinner slices a greater fraction of the inhibitory input was from nearby regions and did not require action potentials.

To rule out the possibility that the reduction in glycinemediated currents by TTX was attributable to some action on the ability of the ganglion cell to respond to glycine, the effect of TTX on inhibitory currents elicited by locally applied puffs of glycine was tested. The current traces in Figure 8 were obtained when the cell was voltage-clamped at $0 \mathrm{mV}$ to eliminate excitatory inputs and in the presence of $150 \mu \mathrm{M}$ picrotoxin to block GABAmediated responses. The puff-evoked IPSCs were blocked by 2 $\mu \mathrm{M}$ strychnine but not by $500 \mathrm{~nm}$ TTX. This indicates that the effect of TTX on the light-evoked inhibitory current was attributable to an action on the glycinergic input pathway rather than to some effect of TTX on the ability of the ganglion cell to respond to glycine.

\section{Effect of strychnine and tetrodotoxin on light-evoked excitatory inputs to ganglion cells}

Because there is evidence for glycine-mediated synaptic input onto bipolar cell axon terminals in tiger salamander (Maple and $\mathrm{Wu}, 1998)$, it is of interest to know whether these inputs also contribute to TLI. We looked for evidence of such a presynaptic or disfacilitatory component of TLI by examining the effects of strychnine and TTX on the light-evoked excitatory currents in ganglion cells, because the excitatory currents presumably reflected transmitter release from bipolar cells. Light-evoked

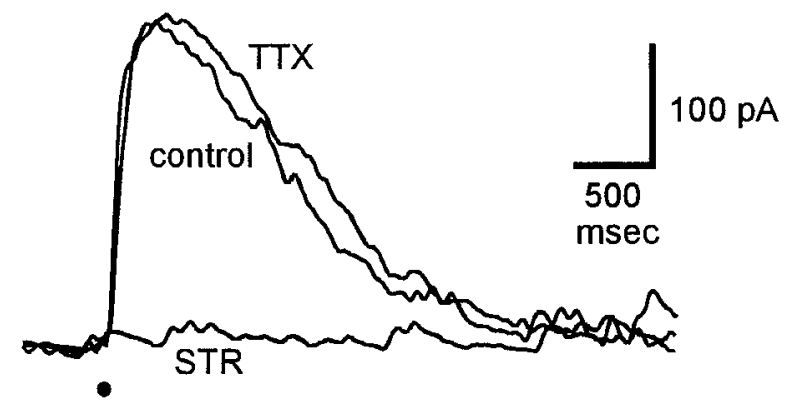

Figure 8. Effect of strychnine and TTX on responses to direct application of glycine. The superimposed traces show IPSCs recorded from the same ganglion cell in control solution (control), in the presence of $2 \mu \mathrm{M}$ strychnine $(S T R)$, and in the presence of $500 \mathrm{~nm}$ TTX. The cell was voltage-clamped at $0 \mathrm{mV}$ to eliminate excitatory currents, and the control solution contained $150 \mu \mathrm{M}$ picrotoxin to block GABA-mediated responses. Responses were elicited by a $5 \mathrm{msec}$ puff of $0.5 \mathrm{~mm}$ glycine from a pipette located in the inner plexiform layer just above the ganglion cell. The dot below traces indicates time of glycine puff. Holding current was $35 \mathrm{pA}$.

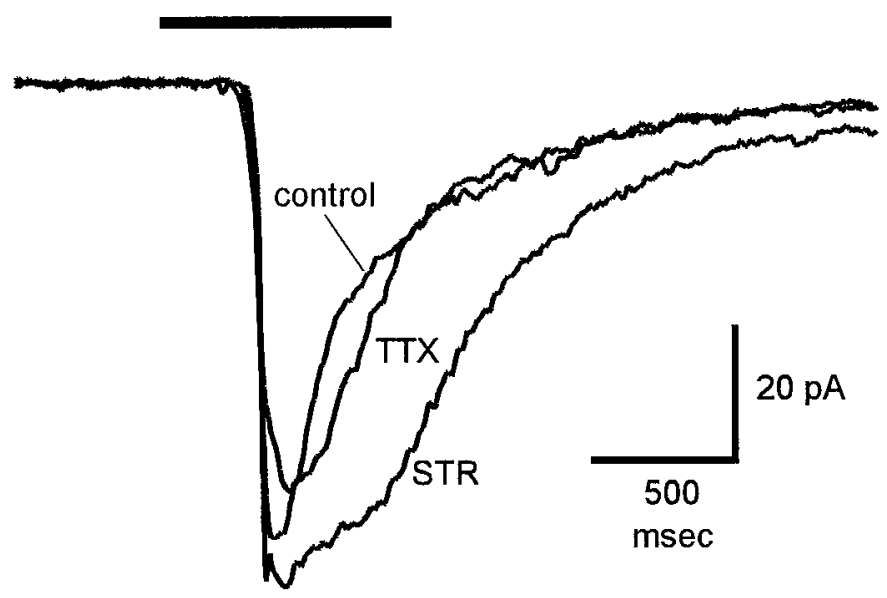

Figure 9. Effect of strychnine and TTX on excitatory input to ganglion cells. The superimposed traces show the inward currents elicited by the same diff use light flash (indicated by horizontal line above responses) in control solution (control) and in the presence of $2 \mu \mathrm{M}$ strychnine (STR) and $500 \mathrm{~nm}$ TTX. Strychnine was applied after recovery following washout of TTX. Bath contained $150 \mu \mathrm{M}$ picrotoxin. Cells were voltageclamped at the reversal potential for chloride ions $(-65 \mathrm{mV})$ to eliminate glycine-mediated responses. Holding current was $-12 \mathrm{pA}$.

EPSCs were isolated by voltage-clamping ganglion cells at the reversal potential for chloride ions $(-65 \mathrm{mV})$ to eliminate the inhibitory currents. For consistency with the other experiments in the slice, the bathing solution also contained $150 \mu \mathrm{M}$ picrotoxin to block GABA-mediated responses. Figure 9 shows the effects of strychnine and TTX on EPSCs isolated in this manner. Strychnine did not cause a change in the holding current in darkness, but it caused a significant increase in the light-evoked EPSC. This result was seen in four of the five cells tested; it had no effect on the EPSC in one cell. The increase in EPSC amplitude in the presence of strychnine was likely caused by the blocking of light-evoked glycinergic input to bipolar cells. In this cell, $500 \mathrm{~nm}$ TTX had little effect on the EPSC. The effect of TTX on the EPSC was variable, but in the five cells tested it was always much smaller than that of strychnine. This suggests that in bipolar cells a large fraction of the glycinergic input does not require action potentials and therefore may come from nearby amacrine cells. 


\section{DISCUSSION}

The results of these experiments show that in mud puppy and salamander retinas TLI and the associated hyperpolarization and conductance increases in ganglion cells are mediated by glycinergic amacrine cells and do not require GABA, and that the lateral spread of this transient glycinergic inhibition in the retina requires action potentials. In some ganglion cells, the effect of rotating the windmill pattern was primarily a sustained hyperpolarization that shifted the spot response to a more hyperpolarized level with relatively little change in its amplitude, but in other ganglion cells windmill rotation also caused both a hyperpolarization and a significant reduction in spot response amplitude. The relative contributions of these two effects varied considerably among ganglion cells in both mud puppy and tiger salamander. The functional significance of these differences is not known and will require further study. However, both effects were always blocked by strychnine and TTX, indicating that both were the result of laterally transmitted glycinergic inhibition.

The fact that transient glycinergic inhibition was elicited by illumination of the receptive field center, as well as by surround (windmill) stimuli, indicates that transient glycinergic inhibition has both local and lateral components. Because the receptive field of the glycinergic inhibitory input is much wider than that of the excitatory input to ganglion cells, Lukasiewicz and Werblin (1990), illumination of the receptive field center with a $400-\mu \mathrm{m}-$ diameter spot elicits both excitation and transient glycinergic inhibition, whereas distant light stimuli such as the $1200 \mu \mathrm{m}$ i.d. windmill patterns elicit only TLI. The fact that TLI elicited by windmill stimuli of 500-1200 $\mu \mathrm{m}$ i.d. was blocked in the presence of TTX indicates that the lateral spread of the TLI signal in the inner retina requires action potentials. However, because TTX did not block the transient glycinergic inhibition elicited by illumination of the receptive field center and did not block all of the glycinergic IPSCs elicited by diffuse light stimuli in the slice recordings, transient glycinergic inhibition near the site of illumination probably does not require action potentials. The greater effectiveness of TTX in blocking glycinergic IPSCs elicited by laterally displaced versus local electrical stimulation supports this idea.

The finding that light-evoked excitatory inputs to ganglion cells were enhanced in the presence of strychnine indicates that light also activates glycinergic inhibition of bipolar cell output. Because this effect of strychnine was not mimicked by TTX, it is likely that most of the glycinergic input to bipolar cell terminals comes from nearby amacrine cells. The present results thus establish a functional role for the recently described glycinergic inputs to bipolar cell terminals in tiger salamander retina (Maple and $\mathrm{Wu}, 1998)$.

The simplest explanation of these results is that transient glycinergic inhibition elicited by both local and distant illumination is mediated by the wide-field transient amacrine cells described by Cook and Werblin (1994). These cells receive excitatory input near the soma and generate action potentials that propagate away from this area over long processes. Figure 10 shows the basic elements of the proposed circuitry for the glycinergic wide-field transient amacrine cell. These cells receive excitatory input from bipolar terminals near the soma and make output synapses onto bipolar and ganglion cells at sites both near the input region and on the long processes. Depolarization from the excitatory inputs near the soma spreads passively to nearby transmitter release sites, but action potentials are required for

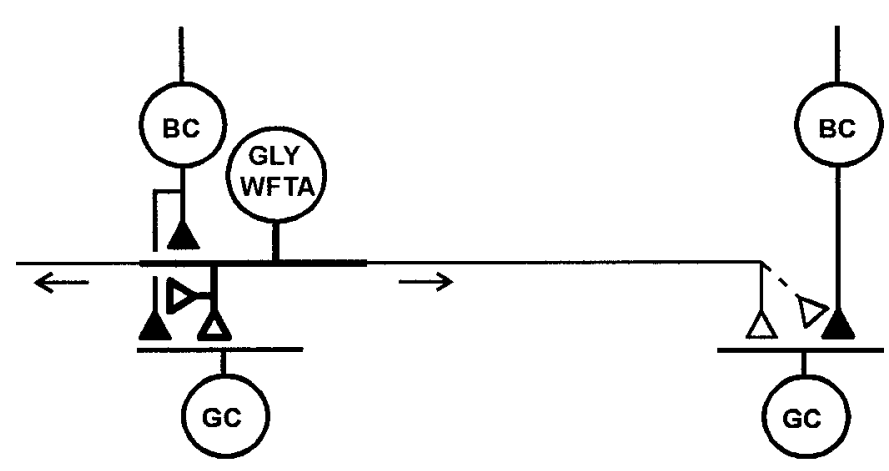

Figure 10. Proposed pathway for TLI in mud puppy and salamander retina. Filled and open terminals indicate excitatory and inhibitory synapses, respectively. Glycinergic wide-field transient amacrine cells (GLY $W F T A$ ) receive excitatory input from bipolar cells $(B C)$ over a restricted region near their somas and send action potentials laterally (arrows) over long processes (thin lines). Output synapses are onto bipolar terminals and ganglion cell dendrites. It is not known whether GLY-WFTA cells also make feedback synapses onto the bipolar terminals from which they receive excitatory input. Depolarization produced by excitatory inputs can spread passively (over region indicated by thick processes) to affect glycine release at nearby sites, but action potentials are required to elicit glycine release at distant sites (region indicated by thin processes). Alternatively, some or all of the short-range TTX-resistant transient glycinergic inputs to bipolar and ganglion cells may come from a separate population of glycinergic narrow-field transient amacrine cells (not shown). In addition to their role in mediating TLI, glycinergic amacrine cells may also make synapses onto GABAergic amacrine cells (not shown).

transmission of this signal to the more distant release sites. In the diagram of Figure 10, the thick processes of the wide-field amacrine cell indicate the region over which transmitter release can by elicited by passive spread of the input signals (local output region), and the thin processes indicate the more distant regions over which information is conducted only via action potentials. Because most of the light-evoked, transient glycinergic input to bipolar terminals appears to be resistant to TTX, the action potential-dependent portion of the glycinergic input to bipolar terminals is shown as a dashed line. Because the wide-field transient amacrine cells typically generate only a single action potential at the onset or termination of a light stimulus, the "sustained" inhibition produced in ganglion cells by rotation of a distant, concentric windmill pattern is likely attributable to the temporal summation of IPSPs produced by action potentials generated in many different wide-field transient amacrine cells that are successively activated as the windmill vane edges pass over their input regions.

In the above circuit the wide-field transient amacrine cell releases glycine both locally and at distant sites. It is also possible that the local (TTX-resistant) transient glycinergic input to bipolar and/or ganglion cells may come from a separate population of narrow-field glycinergic transient amacrine cells that have not yet been described. At present we cannot distinguish between these possibilities. If local and laterally conducted transient glycinergic inhibition are mediated by the same cell type, as suggested above, then it is appropriate to consider transient glycinergic inhibition as a wide-field mechanism, including both local and lateral components, the latter of which is referred to as TLI.

The circuit in Figure 10 also does not show any glycinergic feedback from the wide-field transient amacrine cells onto the bipolar terminals from which they receive excitatory input. It is not known whether such feedback synapses exist, but this cer- 
tainly is a possibility because a given bipolar terminal may synapse onto both ganglion and amacrine cells.

Although picrotoxin did not block TLI in ganglion cells, in some cases it caused an increase in the transient glycinergic IPSP at the onset of a windmill stimulus and the glycinergic sustained hyperpolarization elicited by rotation of the windmill. This observation suggests that GABAergic neurons may modulate the pathway mediating TLI, and such modulation may be one function of the recently reported reciprocal inhibitory interactions between GABAergic and glycinergic amacrine cells (Roska and Werblin, 1997; Zhang et al., 1997). The effects of GABA antagonists on glycinergic inhibitory inputs to ganglion cells are quite complicated, however, and much additional work is necessary before the role of GABA in modulating TLI can be understood.

TLI evoked by rotating windmill patterns is not a peculiarity of amphibians; it has also been described in cat retina (EnrothCugell and Jakiela, 1980). A type of wide-field transient amacrine cell that appears to receive excitatory input over a narrow range near the soma and send information laterally over long axonal processes via action potentials has been described recently in rabbit retina (Taylor, 1996). Although the transmitter used by these cells is not known, their properties are similar to those of the wide-field transient amacrine cells in salamander, and such cells would be well suited for mediating long-range TLI. It is not known whether TLI in mammalian retinas is mediated by glycine or whether its lateral spread requires action potentials.

Because TLI is concerned with changes in illumination, it is tempting to speculate that it may have something to do with directional selectivity. In mammalian retinas, directional selectivity is believed to involve mainly GABA (Caldwell et al., 1978; Kittila and Massey, 1997), but it has been suggested that glycine may play a role in directional selectivity of ganglion cells in amphibian retinas (Pan and Slaughter, 1991).

The role of amacrine cell action potentials in retinal signaling is not completely understood. In rabbit retina, TTX reduced the spread of signals within the dendritic arbors of large-field amacrine cells but not in small-field amacrine cells or in any ganglion cells (Bloomfield, 1996); although TTX did not affect ganglion cell receptive field center size, no other receptive field properties were examined in that study. In tiger salamander retina, TTX blocked the inhibition of amacrine cells by laterally displaced transretinal current stimulation (Barnes and Werblin, 1987), but its effect on ganglion cell receptive field organization was not studied. The present results are the first demonstration that action potentials are required for the lateral transmission of light-evoked signals affecting ganglion cell receptive field organization. One might ask why action potentials are necessary, because lateral transmission of signals over similar distances via horizontal cells in the outer retina does not require action potentials. One reason may be that the increased speed of conduction afforded by action potentials is more important for TLI, because TLI signals changes in illumination rather than steady illumination. Another possibility is that the processes of the amacrine cells mediating TLI must be small in diameter because of space restrictions in the inner plexiform layer, and the resulting short length constants do not allow passive spread of signals for any significant distance in the inner plexiform layer. If this is the case, then it is possible that other types of lateral signaling over any appreciable distance in the inner retina may also require action potentials. We are currently studying this possibility.

\section{REFERENCES}

Barnes S, Werblin FS (1987) Direct excitatory and lateral inhibitory synaptic inputs to amacrine cells in the tiger salamander retina. Brain Res 406:233-237.

Belgum JH, Dvorak DR, McReynolds JS (1984) Strychnine blocks transient but not sustained inhibition in mud puppy retinal ganglion cells. J Physiol (Lond) 354:273-286.

Bloomfield S (1996) Effect of spike blockade on the receptive-field size of amacrine and ganglion cells in the rabbit retina. J Neurophysiol 75:1878-1893.

Caldwell JH, Daw NW, Wyatt HJ (1978) Effects of picrotoxin and strychnine on rabbit retinal ganglion cells: lateral interactions for cells with more complex receptive fields. J Physiol (Lond) 276:277-298.

Cook PB, McReynolds JS (1998) Modulation of sustained and transient lateral inhibitory mechanisms in the mud puppy retina during light adaptation. J Neurophysiol 79:197-204.

Cook PB, Werblin FS (1994) Spike initiation and propagation in widefield transient amacrine cells of the salamander retina. J Neurosci 14:3852-3861.

Enroth-Cugell C, Jakiela HG (1980) Suppression of cat retinal ganglion cell responses by moving patterns. J Physiol (Lond) 302:49-72.

Kittila CA, Massey SC (1997) Pharmacology of directionally selective ganglion cells in the rabbit retina. J Neurophysiol 77:675-689.

Lukasiewicz PD, Werblin FS (1990) The spatial distribution of excitatory and inhibitory inputs to ganglion cell dendrites in the tiger salamander retina. J Neurosci 10:210-221.

Lukasiewicz PD, Maple BR, Werblin FS (1994) A novel GABA receptor on bipolar cell terminals in the tiger salamander retina. J Neurosci 14:1202-1212.

Maple B, Wu SM (1998) Glycinergic synaptic inputs to bipolar cells in the salamander retina. J Physiol (Lond) 506:731-744.

Pan Z-H, Slaughter MM (1991) Control of retinal information coding by $\mathrm{GABA}_{\mathrm{B}}$ receptors. J Neurosci 11:1810-1821.

Roska BM, Werblin FS (1997) Inhibitory interactions between inhibitory amacrine cells in the tiger salamander retina. Invest Ophthalmol Vis Sci [Suppl] 38:1141.

Taylor WR (1996) Response properties of long-range axon-bearing amacrine cells in the dark-adapted rabbit retina. Vis Neurosci 13:599-604.

Thibos LN, Werblin FS (1978) The properties of surround antagonism elicited by rotating windmill patterns in the mud puppy retina. J Physiol (Lond) 278:101-116.

Werblin FS (1972) Lateral interactions at inner plexiform layer of a vertebrate retina: antagonistic responses to change. Science 175:1008-1010.

Werblin FS, Copenhagen DR (1974) Control of retinal sensitivity. III. Lateral interactions at the inner plexiform layer. J Gen Physiol 63:88-110.

Yang Y, Lukasiewicz PD, Maguire G, Werblin FS, Yazulla S (1991) Amacrine cells in the tiger salamander retina: morphology, physiology, and neurotransmitter identification. J Comp Neurol 312:19-32.

Zhang J, Jung C-S, Slaughter MM (1997) Serial inhibitory synapses in retina. Vis Neurosci 14:553-563. 